\title{
PENINGKATKAN MUTU PENDIDIKAN MASYARAKAT MELALUI KEGIATAN PEMBELAJARAN
}

\section{IMPROVING QUALITY OF PUBLIC EDUCATION THROUGH LEARNING ACTIVITY}

\author{
H Makarim ${ }^{1 a}$ dan A Syahrul ${ }^{2}$ \\ 1Program Studi Pendidikan Guru Sekolah Dasar, Fakultas Keguruan dan Ilmu Pendidikan, \\ Universitas Djuanda Bogor, Jl. Tol Ciawi No.1 Kotak Pos 35 Bogor 16720 \\ 2Program Studi Manajemen Pendidikan Islam, Fakultas Keguruan dan Ilmu Pendidikan, \\ Universitas Djuanda Bogor, Jl. Tol Ciawi No.1 Kotak Pos 35 Bogor 16720 \\ a Koresponsdensi: Helwiyah Makarim, Email: helwiyahmakarim@yahoo.co.id \\ (Diterima: 01-11-2016; Ditelaah: 01-11-2016; Disetujui: 09-01-2017)
}

\begin{abstract}
Learning is an activity that was takes place in an active interaction with the environment, resulting in changes in knowledge, skills and attitudes. Recognizing the learning process can be recognized when there is be a change in behavior of someone after he interacts with his environment. Learning in question is to study knowledge in the mother's womb to get to the grave, which is a life period that cannot be separated from learning activities, from birth until life is over.
\end{abstract}

Keywords: community environment, learning, public education.

\begin{abstract}
ABSTRAK
Belajar merupakan kegiatan yang berlangsung dalam interaksi aktif dengan lingkungan, yang menghasilkan perubahan-perubahan dalam hal pengetahuan, keterampilan, dan sikap. Mengenali proses belajar dapat dikenali ketika adanya perubahan perilaku dari seseorang setelah ia berinteraksi dengan lingkungannya. Belajar yang dimaksud ialah menuntut ilmu sejak di kandungan ibu hingga sampai ke liang lahat, yaitu masa kehidupan yang tidak terlepas dari kegiatan belajar, sejak mulai lahir sampai hidup ini berakhir.

Kata kunci: lingkungan masyarakat, pembelajaran, pendidikan masyarakat.

Makarim H dan A Syahrul. 2017. Peningkatkan mutu pendidikan masyarakat melalui kegiatan pembelajaran. Qardhul Hasan: Media Pengabdian kepada Masyarakat 3(1): 1-14.
\end{abstract}

\section{PENDAHULUAN}

Saat ini dapat diakui bahwa pendidikan merupakan hal utama dalam membangun bangsa ini secara integral (secara keseluruhan), dan komprehensif (menerima dengan baik). Sebab karena itu haruslah pendidikan dijadikan prioritas utama bila kita menginginkan kelak negeri ini menjadi makmur dan maju. maka kunci jawabannya harus dimulai dan didasari dari pendidikan berkulitas untuk anak - anak bangsa hingga terciptanya manusia tangguh, berkarakter, kreatif, bermartabat, dan berpengetahuan luas serta memiliki akhlakul karimah (berbudi luhur).

Penelitian tersebut meliputi 5 indikator di antaranya ialah pemerintahan (governance), ketersediaan (availability), aksebilitas (acceptability), dan adaptasi (adaptability). Adapun urutan peringkat pendidikan dari 14 negara yang mengikuti acara tersebut dapat dilihat pada tabel di bawah ini. 
Tabel 1 Kualitas pendidikan berdasarkan Right To Education Index (RTEI)

\begin{tabular}{llc}
\hline \multicolumn{1}{c}{ Peringkat } & Nama negara & Skor \\
\hline Pertama & Inggris & $87 \%$ \\
Kedua & Kenada & $85 \%$ \\
Ketiga & Australia & $83 \%$ \\
Keempat & Filipina & $81 \%$ \\
Kelima & Ethiopia & $79 \%$ \\
Keenam & Korea selatan & $79 \%$ \\
Ketujuh & Indonesia & $77 \%$ \\
Kedelapan & Nigeria & $77 \%$ \\
Kesembilan & Hounduras & $77 \%$ \\
Kesepuluh & Palestina & $76 \%$ \\
Kesebelas & Tanzania & $73 \%$ \\
\hline
\end{tabular}

Berdasarkan dari Tabel 1, dapat disimpulkan bahwa Indonesia menempati urutan ke-7 dengan posisi masih berada pada tingkat bawah dari negara Ethiopia dan Korea Selatan dan medapatkan nilai yang sama dengan dua negara yaitu dari Nigeria dan Hounduras. Dikarenakan 3 Faktor diantaranya ialah:

Pertama availability yaitu ketersediaan, kualitas guru yang rendah sebab tidak meratanya ketersediaan guru pada daerah terdepan, terjauh, dan terpencil atau pedesaan.

Kedua adaptability yaitu adaptasi, lingkungan sekolah yang belum ramah terhadap anak, seringkali terjadinya kekerasan, diikuti dengan pelecehan seksual yang kerap terjadi di sekolah, yang masih menjadi bulan - bulanan di media sosial, dan kurangnya pengawasan di sekolah sehingga terjadinya penculikan anak.

Ketiga acceptability yaitu penerimaan, akses pendidikan untuk sekelompok marginal (buruh anak, seseorang/ sekelompok/ masyarakat yang mendapatkan perlakuan tidak adil, karena permasalahan yang memiliki gender, atau yang pernah mengalami peminggiran sosial, atau sekelompok masyarakat yang pada hak asasinya terlanggar), yang belum bisa memberikan hak pendidikan seutuhnya bagi anak - anak tersebut.
Kejadian tersebut tidaklah berbeda jauh dengan halnya permasalahan pendidikan di kalangan masyarakat, berdasarkan dari hasil pengamatan yang dilakukan oleh mahasiswa KKN dalam program pengabdian masyarakat, kampung kandang Sapi, bertempatan di desa Barengkok, dari kecamatan Leuwiliang Kabupaten Bogor Barat, yang menunjukan bahwa masih ditemukan pada kalangan pendidikan anakanak usia dini, sampai dengan anak sekolah menengah pertama dan atas, mengenai kurangnya minat belajar pada diri mereka, begitu pula pada kalangan orangtua.

\section{MATERI DAN METODE}

\section{Materi}

Pada kegiatan belajar dan mengajar pada program pembelajaran ini, memiliki berbagai macam materi yang digunakan pada kegiatan tersebut dan untuk materi pertama untuk kegiatan pembelajaran Baca Tulis Al Qur`an (BTQ), yang menggunakan materi / metode tilawati, yaitu metode praktis cepat tartil membaca Al Quran. Metode tersebut menekankan bagaimana mengajarkan Al Qur`an kepada murid dengan pendekatan seni optimalisasi otak kanan dalam belajar Al Qur`an. Yaitu akan lebih menyenangkan sehingga murid tidak merasa bosan saat belajar", ujarnya dari trainer tilawati cabang Balik Papan, Kalimantan Timur. Pada acara Mi’raj Islamic News Agency (MINA).

Kelebihan metode tilawati adalah suatu metode mengajar membaca Al Qur`an sesuai dengan kaidah dan aturan dari ajaran Rasulullah Saw. Mereka para ahli praktisi pengajar Al Qur’an melakukan penelitian dari berbagai metode yang ada, di berbagai penjuru tempat di Indonesia dan pada akhirnya melahirkan metode tilawati. Adapun metode tilawati adalah salah satu dari sekian banyak metode mengajar $\mathrm{Al}$ Qur’an di dunia islam. Penekanannya adalah dengan metode yang dikolaborasikan dengan nada atau lagu serta penempatan waktu yang efesien sehingga semua murid 
mendapatkan waktu yang sama dalam kegiatan belajar - mengajar (KBM), selain itu, metode tilawati juga sangat menekankan pada pengajaran dengan pendekatan seni dengan melagukan setiap materi yang diberikan oleh guru kepada murid - murid, yaitu menggunakan seni baca Al Qur`an dengan lagu dasar Al Qur’an. Dalam prakteknya menggunakan teknik klasikal baca simak, dengan teknik berikut dapat mencapai target berupa kurikulum yang baik dan berkualitas.

Yaitu sejak tahap pertama, guru sudah mengajarkan kepada murid - murid dengan teknik tilawati pada setiap halaman sehingga memudahkan mereka dalam mengingatnya, pengenalan lagu - lagu dalam melantunkan bacaan Al Qur`an sendiri memungkinkan lebih efektif bagi murid - murid guna memudahkan untuk melancarkan bacaan $\mathrm{Al}$ Qur`annya.

Metode tilawati pertama kalinya direalisasikan di salah satu pondok pesantren Al Qur`an Nurul Falah Surabaya, dinamakan tilawati sendiri karena mempunyai kesemangatan dan minat belajar Al Qur`an yang baik dari para pengurus Tilawati Center dalam terwujudnya sebuah lembaga pendidikan dakwah sebagai pusat peningkatan mutu guru - guru Al Qur`an melalui peningkatan skill membaca Al Qur`an dari berlatih dan dibina bersama yang telah dijadikan program dari metode tersebut, sebagaimana diketahui pertumbuhan di lembaga - lembaga yang menyelenggarakan pembelajaran Al Qur`an di berbagai tempat dipelosok penjuru di Indonesia yang terus bertambah banyak, baik pendidikan formal, maupun pendidikan nonformal, namun demikian tidak terlepas dengan persolan yang meliputi bidang tersebut.

Mulai dari guru Al Qur`an yang belum memenuhi standart dalam bacaan Al Qur`an, mutu lembaga yang tidak berjalan optimal, dalam hal pendekatan terhadap murid dan penggunaan metode pembelajaran yang membosankan peserta didik, dan sebagainya, maka tilawati center bertekad dalam membantu persoalan tersebut dengan menjadikan model pembelajaran Al Qur’an yang selaras dan sesuai dengan tuntunan dan ajaran Allah dan Rasulnya, adapun visi dari lembaga tersebut yaitu menjadi lembaga pendidikan berbasis tauhid dan pendidik yang profesional dan sebagai pusat tempat pendidikan. Serta pengembangan pada $\mathrm{Al}$ Qur`an, dan misinya adalah sebagai pembangun lembaga pendidikan Al Qur`an dan terwujudnya guru pengajar Al Qur`an yang berkualitas, dan mengembangkan ilmu - ilmu yang berkaitan dengan pengajaran $\mathrm{Al}$ Qur`an.

Secara umum metode tilawati dibagi menjadi tiga tahapan: tahap pertama, membaca Al Qur`an dengan fasih sesuai dengan lagu rosy dan kaidah - kaidah yang benar, kedua, tahap pemahaman dari segi terjemahan dan tafsir Al Qur`an, dan tahap ketiga, yaitu latihan secara khusus dalam mengajar Al Qur`an dengan tertib dan efektif.

Selanjutya untuk materi yang disampaikan pada pelajaran Bahasa Arab yaitu menggunakan metode Bahasa arab qowaid dan tarjamah metode ini adalah kolaborasi dari metode gramatika dan metode terjemah, yang merupakan cara mempelajari Bahasa Arab yang mengarah pada metode tersebut ataupun kaidah kaidah Bahasa untuk mencapai sebagian dari empat keterampilan Bahasa, yaitu membaca, menulis, memahami dan menterjemah.

Metode qawaid dan tarjamah dapat dikatakan lebih ideal dari salah satu ataupun kedua metode tersebut (gramatika dan terjemah), sebagaimana diketahui bahwa metode tersebut merupakan sebuah metode untuk dapat menterjemahkan dari Bahasa ibu yang diterjemahkan dalam bahasa sasaran atau bahasa penerima yang tidak bisa lepas dari penerapan aturan - aturan tata bahasanya, yang memfokuskan pada kegiatan penerjemahan bacaan dari Bahasa asing ke dalam Bahasa atau sebaliknya. Sedangkan metode qawaid merupakan metode yang membahas kepada penghafalan aturan - aturan gramatika dan sejumlah kosakata atau kata tertentu, yang dirangkaikan menurut susunan Bahasa yang berlaku, yang merupakan metode tertua dalam Bahasa asing sehingga disebut juga 
metode tradisional, yang dilakukan dengan kegiatan membaca serta menulis sambil menyanyi dan bermain,guna menjadikan suasana pembelajaran dan pengajaran berjalan aktif dan interaktif, metode tersebut dilatarbelakangi oleh adanya kebutuhan untuk mempelajari serta mengajarkan Bahasa asing, untuk dapat menyampaikan Bahasa peradaban di masa lampau, selain itu juga bermuara pada zaman dimana bangsa eropa yang pada masa itu bahasa yunani dan Bahasa latin dipakai untuk dapat menyalurkan warisan yang bersifat kemanusiaan dan peradaban ke dunia barat yang diterjemahkan dan ditulis di berbagai macam Bahasa.

Metode qowaid dan tarjamah dikenal dengan sebutan metode tradisional karena mungkin secara sepintas julukan ini memberi kesan " metode lama" yang berusia sudah cukup tua, akan tetapi bukan masalah usianya yang tua, namun yang penting dan menarik adalah fakta bahwa metode qawaid dan tarjamah sudah melekat dengan kuat dikalangan masyarakat.

Kemudian selanjutnya untuk metode pembelajaran Bahasa inggris menggunakan metode phonetic yang merupakan sebuah hubungan antara bunyi yang dapat diwakilkan oleh alphabet secara tercetak, system phonic merupakan system yang terkait system bunyi yang dapat dikenalkan dalam alphabet atau huruf, yang bertujuan murid dapat mengenal dan menyebutkan huruf A sampia Z yang terdapat pada Bahasa inggris baik secara berurutan maupun secara acak, dan metode tersebut dapat dijadikan oleh guru sebagai pedoman untuk mengenalkan lambing huruf dalam belajar Bahasa inggris bagi anak usai dini sampai dengan anak dewasa. Pada penerapanya guru kegiatan dilakukan dalam dua tahap, pertama siswa bermain huruf yang berlangsung selama 10 menit dan kedua murid mengerjakan latihan pada lembar jawaban yang dilakukan selama 20 menit, seperti hal menebak gambar yaitu guru membunyikan 2-3 huruf kemudian siswa berlomba mencari gambar yang sama dengan bunyi huhuf yang telah disebutkan oleh guru. Kemudian guru dapat mengatahui dan melihat dengan jelas mana murid yang telah menguasai pelajaran serta mana murid yang masih memerlukan bimbingan untuk mengenal bunyi huruf, dan untuk mengetahui pemahaman murid dalam mengerjakan lembar kerja siswa , mereka harus mengenal bunyi dengan mengerjakan lembar kerja siswa tersebut yaitu murid diminta untuk mencocokkan gambar pada bunyi huruf. Pada kegiatan tersebut dapat diamati oleh murid - murid yang telah mengerti ataupun belum mengerti pelajaran.

Untuk kegiatan pembelajaran terakhir yaitu penggadakan dalam kegiatan sosialisasi pendidikan PAUD, pada pengertianya sosialisai merupakan proses penanaman atau transfer kebaiasaan atau nilai dan aturan dari satu generasi lainnya dalam sebuah kelompok atau masyarakat, sosialisasi diartikan sebagai sebuah proses seumur hidup, bagaimana individu mempelajari kebiasaan cara - cara yang baik untuk hidup, nilai- nilai pada norma - norma sosial yang terdapat pada kehidupan masyarakat agar diterima bagi kalangan masyarakat.

Dalam proses sosialisasi individu atau kelompok berkembang menjadi satu kepribadian atau bidang sosial, karena perkembangan kepribadian manusia dipengaruhi oleh beberapa faktor diantarannya: pertama, sifat dasar, yaitu sifat - sifat yang diwarisi individu dari kedua orangtuanya, sifat dasar ini banyak dipengaruhi dalam perkembangan kepribadian indivdu dan kegiatan untuk sosialiasi tersebut menggunakan metode tanya jawab pada kegiatan sosialisasi guna mengetahui persoalan - persoalan yang kerap dihadapi oleh para guru terhadap peserta didiknya di sekolah, dan memecahkan masalah tersebut dengan baik.

\section{Metode}

Pada penulisan karya tulis ini merupakan metode deskriptif, yaitu merupakan metode penelitian yang mengambarkan dan menginterpretasi objek sesuai dengan realitanya atau apa yang terjadi sesungguh - 
sungguhnya di lapangan. Penelitian ini juga sering disebut tanpa perlakuan, Karena penelitian ini peneliti tidak melakukan pengawasan dan memanipulasi variabel penelitian.

Dengan metode deskriptif, peneliti memungkinkan untuk melakukan hubungan antarvariabel, menguji hipotesis, mengembangankan generalisasi, dan mengembangkan teori yang memiliki validitas universal ( West, 1928).

Walaupun sebenarnya tidak demikian kenyataanya, karena penelitian ini sebernanya juga ditampilakan dalam bentuk yang lebih kompleks, misalnya adalah pada penelitian penggambaran tentang faktual tentang perkembangan di sekolah, sekelompok anak, perkembangan individual. Penelitian deskriptif juga dapar dikembangan ke arah penelitian naturalistik yang menggunakan kasus yang spesifik melalui deskritif mendalam atau dengan penelitian setting alami dengan pendekatan fenomenologis dan dilaporkan secara mendalam dalam pengambaran peristiwa dengan menggunakan hubungan antarvariabel yang lebih kompleks.

Dalam penelitian deskriptif, peneliti tidak memanipulasi variabel dan tidak mentapkan peristiwa yang akan terjadi, dan biasanya menyangkut peristiwa - peristiwa yang saat sekarang terjadi. Dengan menggunakan penelitian deskriptif ini, peneliti memiliki kemungkinan dalam menjawab jawaban atas pertanyaan penelitian yang terkaitan dengan hubungan yang melakukan variabel atau asosiasi, serta pula mencari hubungan komparasi antarvariabel, dan penelitian deskriptif memiliki keunikan seperti berikut:

Penelitian ini juga menggunakan salah satu sistematik penelitian yaitu kuesioner, wawancara, seringkali memperoleh responden yang minim sekali bahkan sangat sedikit, akibatnya apabila dalam menarik sesuatu yang diteliti untuk dijadikan kesimpulan.

Salah satu teknik yang lain adalah obeservasi, sering sekali dalam proses pengumpulan data tidak dapat memperoleh data yang memadai. Harus diperlukan para observer pembuatan check list lebih dahulu tentang objek yang nantinya dilihat dan diawasi, sehingga mendapatkan data yang diinginkan secara objektif dan reliabel.

Penelitian memerlukan pula permasalahan yang sudah diidentifikasi dan dijadikan rumusan dengan jelas, supaya di lapangan, tidak mengalami kesulitan dalam menemukan, menjaring data yang diperlukan.

Penelitian deksriptif memiliki langkah langkah untuk mengidentifikasi permasalahan yang benar - benar sudah signifikan untuk ditanggani melalui metode deksriptif sebagai berikut:

Pertama, membatasi dengan cara merumuskan pada permasalahan secara Lukas dan jelas, kedua menentukan kepada tujuan dan hasil dari manfaat penelitian, ketiga, melakukan studi kasus pustaka yang terkait terhadap permasalahan, keempat, menentukan kerangka berfikir, dan pertanyaan seputar penelitian atau hipotsis penelitian, kelima, mendesain metode yang hendak akan digunakan termasuk menentukan pada populasi, pada sampel, dan pada teknik sampling, dan menentukan insrumen untuk mengumpulkan data, serta menganalisanya, keenam, mengumpulkan, mengorganisasi, menganalisis dengan data yang akan digunakan pada teknik statisktika yang relevan, ketujuh, membuat laporan penelitian.

Pada tahap analisis data, peneliti membuat deksriptif atau membuat ringkasan data yang menggunakan pada tahap metode dari statistika deskriptif. Disini peneliti berusaha mengdiskripsi dan menginterpretasi data yang dikumpulakan. Pada beberapa studi, misalnya survei angket, seluruh prosedur analisis semata - mata terdiri dari perhitungan dan interpretasi menggunakan metode dari statistika deskriptif.

Metode statistika desktiptif adalah sekumpulan metode yang berupaya membuat ringkasan dan deskripsi data yang sudah terkumpul (missal \% kenaikan atau perubahan), memiliki kemungkinkan peneliti untuk dapat membuat deskripsi nilai 
- nilai yang banyak dengan angka - angka indeks yang simple, tapi penuh arti). Tatkala angka terhadap indeks itu dihitung untuk mendeskripsi sampel yang ditarik dari populasi, angka hasil perhitungan itu merupakan statistika. Apabila angka itu dihitung untuk mendeskripsi populasi keseluruhan, angka itu merupakan parameter, dan harus diingat bahwa pengertian statistika jauh berbeda dengan statistika atau metode statistika. Statistika merupakan angkat yang diperoleh dengan menggunakan metode ini untuk mendeskripsikan sampel. Sedangkan statistika merupakan terjemahan dari "statistics", pengertiannya sama dengan metode statistika.

Jenis metode statistika desktiptif yang terpenting adalah dalam ukuran untuk tendensi sentral, ukuran variabilitas, ukuran hubungan, dan ukuran posisi relatif. Ukuran pada tendensi sentral dapat digunakan tatkala menentukan nilai pada posisi umum (kecenderungan) dari sekelompok nilai. Ukuran variabilitas menunjukan bagaimanakah penyebaran nilai pada suatu total nilai. Ukuran hubungan menujukan seberapakah tigkat hubungan dua kelompok nilai. Sedangkan ukuran posisi relative memberikan deskripsi mengenai prestasi subjek dibandingkan dari penampilan semua objek yang lain, sebelum benar- benar menghitung suatu ukuran statistika, angka banyak membantu apabila data dapat disajikan dalam bentuk grafik.

\section{HASIL DAN PEMBAHASAN}

\section{Hasil}

Seyogianya pendidikan merupakan suatu bidang yang tidak dapat dipisahkan dari masyarakat, karena pendidikan dan pembelajaran mengandung arti bahwasanya memiliki daya adaptabilitas terhadap perubahan lingkungan tanpa menghilangkan identitas dari pendidikan itu sendiri.

Oleh karena itu, dalam era reformasi seperti sekarang ini kita tentunya mengharapkan adanya perubahan dalam bidang pendidikan, paling tidak intesitas (keadaan tingkat) perhatian pada aspek aspek tertentu perlu ditingkatkan.

Perubahan itu tentunya diharapkan dapat memperbaiki keadaan dalam proses belajar dan mengajar menuju kepada mutu pendidikan. Kegiatan pendidikan sebetulnya bukan hanya tugas guru di sekolah. Tetapi keberhasilan pendidikan juga tergantung pada pihak lain selain nguru, yaitu siswa itu sendiri, orang tua, masyarakat dan pemerintahan, sebagai pembuat kebijakan (legal decision). Mengingat bahwa sistem pendidikan nasional harus mampu menjamin pemerataan kesempatan pendidikan, peningkatan mutu serta relevansi dan efesiensi manajemen pendidikan untuk menghadapi tantangan sesuai dengan tuntutan perubahan kehidupan lokal, nasional, dan global sehingga perlu dilakukan pembaharuan pendidikan secara terencana, terarah dan berkesimbungan, sesuai dengan UU Sistem Pendidikan Indonesia dalam bagian"menimbang" butir (c).

Karena pendidikan adalah usaha sadar dan terencana untuk mewujudkan suasana belajar dan proses pembelajaran agar peserta didik secara aktif mengembangkan potensi dirinya untuk memiliki kekuatan spiritual keagamaan, pengendalian diri, kepribadian, kecerdasan, akhlak mulia, serta keterampilan yang diperlukan dirinya, masyarakat, bangsa dan negara (UURI No. 20 / 2003, pasal 1 ayat 1). Selanjutnya, pada pasal 1 ayat 2 (UURI No.20 / 2003) dinyatakan bahwa pendidikan nasional adalah pendidikan yang berdasarkan Pancasila dan Undang - Undang Dasar Negara Republik Indonesia Tahun 1945 yang berakar pada nilai - nilai agama, kebudayaan nasional Indonesia, dan tanggap terhadap tuntunan perubahan zaman. Pendidikan juga merupakan usaha membinadan membentuk pribadi siswa agar bertakwa kepada Allah SWT, cinta kepada orantgtua dan sesame, dan kepada negara, sebagai kaunia yang diberikan oleh Allah SWT. Untuk itu, pendidikan harus menekankan aspek produktivitas dan kreativitas manusia 
sehingga dapat berperan serta berprofesi dalam kehidupan bermasyarakat (Omar Muhammad, 2004: 30).

Adapun tujuan dari pendidikan itu sendiri dilihat dari segi gradasinya, yang terdiri atas tujuan akhir dan tujuan sementara. Dilihat dari sifatnya, ada tujuan umum dan tujuan khusus. Dilihat dari segi penyelenggaraannya terdapat tujuan pendidikan formal, tujuan pendidikan informal, dan tujuan pendidikan nonformal. Dalam pendidikan formal terdapat tujuan pendidikan nasional, tujuan nstitusional, tujuan kurikuler, dan tujuan instruktisional. Dilihat dari output -nya, ada tujuan individual dan tujuan sosial.

Dalam bidang studi (kurikulum), tujuan pendidikan terbagi menjadi tujuan keagamaan, tujuan intelektual, tujuan kultural, tujuan material, dan tujuan psikis.Menurut beberapa tokoh dan pakar pendidikan, tujuan pendidikan adalah sebagai berikut.

Pertama menurut Ahmad Tafsir (1990: 39) menjelaskan tiga tujuan pendidikan, yaitu: a. Berkaitan dengan individu, mencangkup perubahan yang berupa pengetahuan, tingkah laku, jasmani dan rohani, serta kemampuan yang harus dimiliki untuk hidup di dunia dan akhirat. Berkaitan dengan masyarakat, mencangkup tingkah laku masyarakat, tingkah laku individu dalam masyarakat, perubahan kehidupan masyarakat, memperkaya pengalaman masyarakat, dan tanggung jawab sebagai anggota masyarakat.

Berkaitan dengan pendidikan dan pengajaran sebagai ilmu, seni, profesi, dan kegiatan masyarakat.

Kemudian menurut Ibnu Khaldun (1978: 926) mengatakan bahwa tujuan pendidikan ada enam macam, yaitu: pertama, memberikan kesempatan pada pikiran untuk aktif bekerja, Karena hal ini sangat penting bagi perkembangnya pemikiran dan kematangan individu yang dapat bermanfaat bagi masyarakat, kedua, agar manusia memiliki berbagai ilmu pengetahuan yang dapat menjadi alat bantu untuk menjalani kehidupan dengan baik dalam masyarakat yang maju dan berbudaya, ketiga, untuk menjadi lapangan kerja yang dapat dimanfaatkan untuk memperoleh rezeki, keempat, mempersiapkan manusia agar mampu melakukan syiar agama dalam rangka memperkuat keimanannya, kelima, mempersiapkan manusia agar memiliki akhlak karimah, ketujuh, mempersiapkan manusia agar memiliki pendidikan vokasional dan profesional.

Dan adapun menurut Hasan Langgulung (1987:51), tujuan pendidikan dapat dibagi menjadi tiga macam, yaitu tujuan umum, tujuan khusus, tujuan akhir. Tujuan umum adalah maksud atau perubahn yang dihendaki dan diusahakan oleh pendidikan untuk mencapainya. Tujuan ini kurang merata dan lebih dekat dengan tujuan tertinggi, tetapi kurang khusus sehingga sulit untuk dioperasionalkan.

Adapun tujuan khusus adalah perubahan yang diingini merupakan bagian yang termasuk tujuan umum pendidikan. Degan kata lain, gabungan pengetahuan, keterampilan, pola tingah laku, sikap, nilai, dan kebiasaan yang terkandung dalam tujuan akhir atau tujuan umum juga tidak akan terlaksana, tujuan dengan sempurna.

Adapun tujuan akhir adalah pembentukan peribadi khalifah bagi anak didik yang memiliki fitrah, roh di samping badan, kemauan yang bebas, dan akal. Dengan kata lain, tugas pendidikan adalah mengembangkan keempat asek tersebut pada manusia agar dapat menempati kedudukan sebagai khalifah (Hasan Langgulung: 1987: 52). Dan Abdurrahman Al-Nahlawi (1989: 162), mengkuatkan tujuan pendidikan dengan pendapatnya bahwa tujuan pendidikan adalah mengembangkan pikiran manusia dan mengatur tngkah laku serta perasaannya berdasarkan Islam. Dengan kata lain, merealisasikan ubudiyah kepada Allah dalam kehidupan manusia, baik individu maupun masyarakat, jadi, tujuan pendidikan adalah perwujudan penyerahan mutlak kepada Allah, Hamba Allah sebagai individu, masyarakat, dan manusia pada umumnya. 
Bersadarkan tujuan pendidikan yang dikemukakan oleh para pemikir pendidikan tersebut, dapat dipahami bahwa tujuan umum pendidikan adalah mewujudkan manusia yang beriman, bertakwa, cerdas, sehat jasmani dan rohani, memiliki keterampilan memadai, barakhlak mulia, memiliki kesadaran yang tinggi dan selalu intropeksi diri, tanggap terhadap persoalan, mampu memecahkan masalah dengan baik dan rasional, dan memiliki masa depan yang cerah, baik di dunia maupun di akhirat. Adapun nilai - nilai yang menjadi acuan penetapan tujuan pendidikan dan membimbing proses pendidikan adalah sebagai berikut: pertama, nilai material, memelihara keberadaan manusia dari segi materi, kedua, nilai sosial, yang lahir dari kebutuhan manusia untuk berinteraksi dengan sesamanya, ketiga, nilai intelektual yang berkaitan dengan kebenaran pemikiran dan penting bagi para penuntut ilmu, keempat, nilai estetis yang berhubungan dengan apresiasi terhadap keindahan, kelima, nilai etis yang menjadi sumber kewajiban dan tanggung jawab, keenam, nilai religius dan spiritual dan nilai etis, nilai inilah yang menjadi acuan bagi nilai - nilai lainnya.

Sedangkan tujuan umum pendidikan nasional Indonesia diwarnai oleh falsafah dan dasar negara Republik Indonesia, yaitu Pancasila. Kelima sila Pancasila secara jelas tercermin pada usaha pendidikan yang berusaha meningkatkan ketakwaan warga negara terhadap Tuhan Yang Maha Esa, meningkatkan rasa persatuan dan kesatuan berbangsa dan bertanah air, meningkatkan budi pekerti luhur dan sifat - sifat terpuji lain yang sangat berfaedah bagi individu sebagai peserta didik. Selain itu, pendidikan juga meningkatkan kecerdasan peserta didik melalui berbagai ilmu pengetahuan, serta meningkatkan keterampilan dan kemampuan untuk menguasai ilmu pengetahuan dan teknologi yang menguasai berbagai bidang kehidupan.

Secara sistem Pendidikan Nasional dinyatakan bahwa pendidikan bertujuan mencerdaskan kehidupan bangsa dan menggembangkan manusia Indonesia seutuhnnya, yaitu manusia yang beriman dan bertakwa terhadapa Tuhan Yang Maha Esa, dan berbudi pekerti luhur, memiliki pengetahuan dan keterampilan, kesehatan jasmani dan rohani, kepribadian yang mantap dan mandiri serta rasa tanggung jawab kemasyarakatan dan kebangsaan. Menurut Undang - Undang Sistem Pendidikan Nasional No.20 tahun 2003, "Pendidikan nasional berfungsi mengembangkan kemampuan dan membentuk watak serta peradaban bangsa yang bermartabat dalam rangka mencerdaskan kehidupan bangsa, bertujuan untuk berkembangnya potensi peserta didik agar menjadi manusia yang beriman dan bertaqwa kepada Tuhan Yang Maha Esa, berakhlak mulia, sehat, berilmu, cakap, kreatif, mandiri, dan menjadi warga negara yang demokratis serta bertanggung jawab."

Berangkat dari pemahaman tujuan pendidikan nasional seperti tercantum dalam UUSPN No.20 tahun 2003 dalam kaitannya dengan menjadikan sekolah sebagai pusat pembudayaan, pendidikan yang dilaksanakan bermakna sebagai proses pengembangan kemampuan nilai, dan sikap yang relevan dengan tuntutan pembangunan negara kebangsaan Indonesia. Baik UU No.2 tahun 1989 maupun No.20 tahun 2003 tentang Sistem Pendidikan Nasional, membuat bahan kajian dan pelajaran wajib yang dipelajari dari Sekolah Dasar hingga Sekolah Lanjutan Pertama. Arah pendidikan nasional yang diselenggarakan oleh pemerintah adalah membentuk manusia yang memiliki kecerdasan yang tinggi, keterampilan, dan mengembangkan potensi keimanan dan ketakwaan, membentuk manusia yang berakhlak mulia, mempunyai rasa cinta tanah air, bangsa dan negara, menghormati sesame warga negara dan bangsa lain,berbudi luhur, serta memiliki sikap mental demokratis dan bertanggung jawab.

\section{Pembahasan}

Maka perbaikan dalam bidang pendidikan harus didukung oleh semua pihak yang 
terlibat dalam bidang tersebut, oleh karena itu, mahasiswa Kuliah Kerja NyataUniversitas Djuanda Bogor, berinisiatif untuk mengadakan bimbingan belajar bagi masyarakat desa Barengkok pada umumnya, dan bagi kampung kandang sapi khususnya yang meliputi 1 RW dari 6 RT di tempat tersebut, dengan kegiatan tersebut diharapkan dapat menunjang serta meningkatkan mutu pendidikan masyarakat desa dan dapat menyadarkan kepada mereka akan pentingnya pendidikan, yaitu berupa kegiatan baca tulis Al Quran (BTQ), bimbingan belajar (BimBel), pengajian Al Quran di taman pendidikan Al Quran dengan menggunakan metode tilawati, kursus keterampilan seni Hadrah serta Marawis dan pengadaan sosialisasi minat pelajar untuk pendidikan usia dini (PAUD) bagi pendidik di sekolah TK/ TPA/ RA/ dan PAUD sederajat.

Namun tidak sesekali kegiatan kami bentrok dengan kegiatan dan pekerjaan masyarakat di lingkungan tersebut, salah satu contohnya ialah kegiatan baca tulis $\mathrm{Al}$ Quran dengan pekerjaan ibu ibu dan bapak bapak di Kamis pagi pada waktu yang sama juga mereka melakukan kegiatan rutinitas mereka yaitu bekerja, dikarenakan mayoritas penduduk setempat mulai dari kalangan anak - anak sampai orangtua lebih condong bekerja dari pada belajar, dapat dilihat pada grafik 1.

\section{Presentasi Penduduk}

\section{Desa Berdasarkan}

\section{Tingkat Pekerja}

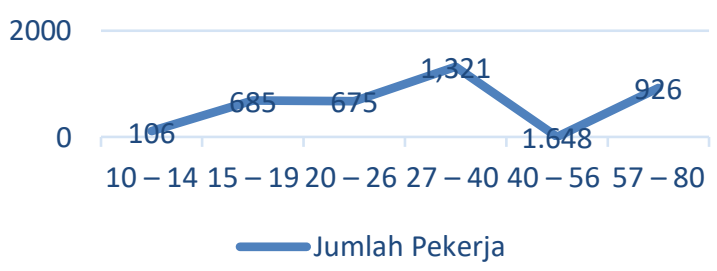

\section{Grafik 1 Presentasi penduduk desa berdasarkan tingkat pekerja}

Pada Grafik 1 di atas menunjukkan kepada tingginya tingkat pekerja di kalangan masyarakat desa, maka harus ada tindakan berupa perhatian khusus di bidang pendidikan dengan menitik beratkan kepada kegiatan mahasiswa Kuliah Kerja Nyata bagi seluruh komponen masyarakat desa yaitu pembelajaran baik di sektor pendidikan formal, informal dan nonformal, adapun penjabaran kegiatan-kegiatan pembelajaran sebagai berikut:

1. kegiatan bimbingan belajar, kegiatan pendidikan informal tersebut menitik beratkan kepada anak - anak usia dini, sampai dengan anak - anak sekolah menengah pertama dan para pemudi.

Yaitu dengan sistem belajar bersama memperluas pengetahuan dan keterampilan baik dalam hal pelajaran yang sama, seperti halnya pelajaran yang dipelajari di sekolah seperti pelajaran menghitung (matematika) agar lebih memahami dan menguasai pelajaran tersebut, serta pelajaran - pelajaran tambahan, salah satu contohnya ialah pelajaran mengenali, memahami, serta mampu menguasai bahasa asing. pembelajaran dilaksanakan dari tanggal 17 Juli s/d tanggal 15 Agustus setiap hari Senin- Jum`at pada pukul $13.00-14.45$ WIB, yang bertempat di salah satu mushola masyarakat setempat mengenalnya dengan nama mushola Nurul Barokah. Pada awal pengajaran syukru wal hamdulillah kami mendapatkan antusias serta tanggapan yang sangat baik dari kalangan masyarakat setempat akan kegiatan kami. Itu ditunjukan dihari pertama kami mengajar, yaitu kepercayaan masyarakat berbentuk 14 anak - anak pada usia dini sampai dengan sekolah dasar yang mengikuti pembelajaran dan diikuti juga dengan penambahan jumlah anak di setiap kegiatan berlangsung pada harihari berikutnya hingga mencapai angka yang tinggi yaitu sampai 43 orang diluar dari dugaan kami, akan tetapi tidak berjalan lama disela sela program kegiatan masih berlangsung tepatnya pada tanggal 3 Agustus kami dikejutkan dengan penurunan tingkat absensi kehadiran peserta didik pada kegiatan bimbingan belajar hingga 6 orang yang tidak mengikuti pembelajaran disetiap 
minggu dan berdampak besar kepada anak - anak yang lain hingga tersisa 25 anak saja, maka kami mengambil tindakan untuk segera menganalisa faktor - faktor menyebab menurunya minat belajar anak, tak lama kemudian keesokan hari data sudah terkumpul dan menyimpulkan bahwa ada sebagian dari anak - anak terbentrok kegiatan mereka dirumah seperti mengaji dengan kegiatan pembelajaran, ada pula dikarenaken masih merasa capek dikarenakan jam pulang sekolah dengan jam mulai kegiatan kami agak berdekatan berkisar 30 menit pada akhrirnya tidak mengikutinya, dan adapula yang mengatakan bahwa bosen dengan model pembelajarannya, yang begitu - begitu saja "kata salah satu anak yang sempat tidak menggikuti pelajaran". Oleh karena itu kami mengambil inisiatif untuk memadukan sylabus pelajaran dengan bermain dan bernyanyi guna menjadikan kegiatan belajar dan mengajar lebih hidup dan interaktif, dan berbuah hasil pada peningkatan jumlah awal anak anak walaupun tidak sebanyak jumlah anak pada awal pembelajaran.

2. Dan program kegiatan harian kami selanjutnya ialah kegiatan pendidikan formal di bidang keagamaan islam yakni pengajian anak - anak di taman pendidikan Al Quran (TPQ), dan kegiatan informal dibidang keagamaan islam yaitu pengajian anak - anak desa yang memfokuskan pada kalangan anak - anak usia dini sampai dengan anak sekolah dasar, bertujuan untuk memberikan pengajaran membaca Al Quran sejak usia dini, serta memahami dasar - dasar dinul islam pada anak usia taman kanak kanak, sekolah dasar dan madrasah ibtidaiyah dimana pembelajaran ditekankan pada pemberian dasar dasar membaca Al Quran serta membantu pertumbuhan dan perkembangan rohani anak. Adapun pelaksanaanya untuk taman pendidikan Al Quran di RT 02, bertempat di mushola $\mathrm{Al}$ - Ibtida dengan waktu pukul $14.30 \mathrm{~s} / \mathrm{d}$
15.30 tepatnya sesudah kegiatan bimbingan belajar dengan hari yang sama yaitu di hari Senin sampai dengan hari Jum`at, yang "berjumlah 21 anak yang terdaftar di TPQ tersebut" kata pembimbing pengajian ujarnya", dan pada setiap hari Kamis dan Jum`at dibekali bagi mereka pelajaran tambahan yaitu seni yang berasal dari negara timur tengah terutama dari Yaman yaitu seni kesenian marawis. Secara keseluruhan kesenian tersebut menggunakan hajir (gendang besar) berdiameter $45 \mathrm{~cm}$ dengan tinggi $60-70 \mathrm{~cm}$, marawis (gendang kecil) berdiameter $20 \mathrm{~cm}$ dengan tinggi $19 \mathrm{~cm}$, dumbuk atau jimbe (sejenis gendang yang berbentuk seperti dandang), memiki diameter yang berbeda pada kedua sisinya, serta dua potong kayu bulat berdiameter $10 \mathrm{~cm}$ dilengkapi dengan tamborin atau krecek dan (symbal) yang berdiameter keciladapun jenis pukulan yang kami ajari ialah zapin, nada zapin sendiri adalah nada yang sering digunakan untuk mengiringi lagu - lagu pujian kepada nabi Muhammad SAW (shalawat) tempo nada zapin lebih lambat dan tidak terlalu menghentak, sehingga banyak juga digunakan dalam mengiringi lagu - lagu melayu. Jumlah pemain untuk kesenian marawis minimal sembilan atau sepuluh orang, setiap orang memainkan satu buah alat sambil bernyanyi. Terkadang untuk membangkitkan semangat, beberapa orang dari kelompok tersebut bergerak sesuai dengan irama lagu, permainan kesenian tersebut dimainkan oleh laki - laki dengan busana gamis dan celana panjang dan berpeci, namun ada juga wanita.

Sedangkan kegiatan pengajian Al Quran di RT 03, bertempat di mushola AlIstiqomah dengan waktu $18.20 \mathrm{~s} / \mathrm{d} 19.00$, adapun anak - anak yang mengaji pada pengajian tersebut berjumlah 23 anak, pengajaran yang sama halnya yang dilakukan di TPQ. Tetapi menggunakan metode yang berbeda yaitu metode tilawati, dan dibekali pula untuk mereka 
kemampuan dalam melantunkan pujian nabi Muhammad SAW (shalawat), tepatnya sesudah pengajaran Al Quran, adapun shalawat yang kami ajarkan ialah shalawat - shalawat sederhana yang tidak terlalu panjang liriknya seperti $\mathrm{Ya}$ assyiqol Mustafa, kisah sang rasul, dan shalawat badriyah.

3. Kegiatan pendidikan nonformal selanjutnya yaitu kegiatan baca tulis $\mathrm{Al}$ Quran (BTQ) yang menitik beratkan kepada ibu - ibu lansia dan ibu - ibu rumah tangga khususnya dan umumnya di kalangan ibu - ibu setempat, yang terhenti belajar di usia muda dan berdampak ketidak mampuan dalam membaca, menulis serta mengaji al qur`an, kegiatan dilaksanakan setiap hari Rabu dan Kamis pada pukul 16.00 s/d 17.30 bertempat di mushola Al-Kautsar RT 01. Adapun ibu - ibu yang mengikuti kegiatan tersebut berjumlah $24 \mathrm{ibu}$ - ibu, dimana pembelajaran untuk lansia yaitu membaca dari melihat tulisan dan menglafalkan apa yang tertulis di papan tulis, serta menulis yaitu membuat huruf, angka dan sebagainya, serta mengaji al qur’an untuk mengetahui huruf - huruf hijaiyah, mengucapkannya dan mampu menulisnya, sementara untuk ibu - ibu yang sudah agak mahir dalam mengaji al - qur'an, menulis dan membaca maka dikhususkan untuk belajar tajwid, guna mencapai kesempurnaan dalam pengucapan lafaz kitab Allah sebagaimana yang disampaikan oleh Nabi Muhammad SAW.

4. Maka pada program kegiatan informal di bidang pendidikan kami mengadakan sosialisasi pendidikan usia dini (PAUD) tertuntuk bagi guru - guru pendidikan usia dini di wilayah kecamatan leuwiliang umumnya, khususnya di desa Barengkok yang mencakup TK,TPA RA,dan PAUD. Tujuan kegiatan adalah untuk meningkatkan pengetahuan para pendidik mengenai peran PAUD dalam meningkatkan mutu pendidikan, membuka wacana mengenai keterkaitan antara peningkatan mutu pendidikan melalui intervensi PAUD, dan menamkan pemahaman bahwa peran PAUD harus menjadi perhatian utama oleh semua pihak, karena dibalik kehebatan dan kemampuan yang dipunyai oleh murid ada kekuatan dan dorongan yang menjadikannya seperti sekarang ini, yaitu guru sebagai pelita dalam kegelapan yang selalu membimbing kepada arah kebenaran, sebagai embun penyejuk, dalam kehausan yang tak terhenti memberikan pelajaran, contoh yang baik, dan nasehat untuk terus menjadi insan yang berbudi luhur, dan engkau sebagai patriot pahlawan bangsa tanpa tanda jasa yang tak mengenal lelah dalam mendidik putra - putri bangsa. Adapun kegiatan tersebut bertempat di masjid Jami Nurul Barokah Leuwimekar dan mengikut sertakan dari ketua HIMPAUDI kecamatan leuwiliang, guru PAUD tingkat desa Barengkok dan diikuti oleh mahasiswa Kuliah Kerja Nyata, yang berjumlah secara keseluruhan sebanyak 27 orang peserta sosialisasi pendidikan usia dini.

\section{Analisis Situasi}

Berdasarkan data yang dihimpun oleh mahasiswa Kuliah Kerja Nyata pada kegiatan pembelajarandan pengajaran serta sosialisasi pendidikan, yang bertujuan dalam meningkatkan mutu pendidikan di masyarakat, dilaksanakan di desa Barengkok, kecamatan Leuwiliang, kabupaten Bogor. Secara umum, wilayah desa Barengkok memiliki jumlah penduduk sebanyak 12.854 jiwa, yang terdiri dari 7068 jiwa laki-laki, dan 5786 jiwa perempuan serta jumlah kepala keluarga sebanyak 3417 KK, untuk data penduduk berdasarkan tingkat pendidikan dapat dilihat pada Tabel 2.

Dari Tabel 2, dapat dilihat dan disimpulkan bahwa tingkat pendidikan di desa tersebut masih terbilang rendah karena output (lulusan) dari setiap intansi pendidikan sangatlah sedikit, maka apabila dikalkulasikan jumlah penduduk yang belum tamat sekolah berjumlah 5297 jiwa. Masih jauh dari harapan terciptanya mutu 
pendidikan, maka dari itu adanya kegiatan pembelajaran yang diadakan oleh mahasiswa kuliah kerja nyata dari Universitas Djuanda Bogor yang diikuti oleh seluruh komponen dalam masyarakat dapat membuahkan hasil yang diharapkan yaitu terciptanya minat belajar yang tinggi sehingga menjadikan pendidikan di desa tersebut pendidikan yang baik dan berkualitas.

Tabel 2 Tingkat pendidikan berdasarkan jumlah penduduk desa.

\begin{tabular}{lr}
\hline \multicolumn{2}{c}{$\begin{array}{c}\text { Jumlah Penduduk berdasarkan tingkat } \\
\text { pendidikan }\end{array}$} \\
\hline Tingkat pendidikan & Jumlah (orang) \\
\hline TK/ TPA/ PAUD & 120 \\
SD/ MI & 614 \\
SMP & 2639 \\
SMA & 3918 \\
D1 - D3 & 169 \\
S1 & 92 \\
S2 & 5 \\
S3 & - \\
Total & 7557 \\
\hline
\end{tabular}

\section{Khalayak Sasaran}

Adanya pengadaan kegiatan pembelajaran baik kegiatan pendidikan formal, nonformal, dan informal tidak lepas dari sasarannya berupa peserta didik yang dibina, dididik dan dibimbing agar terwujudnya mutu pendidikan bagi seluruh penduduk desa Barengkok umumnya dan khususnya bagi penduduk kampung kandang sapi, yang terdiri dari $1 \mathrm{RW}$ dan $6 \mathrm{RT}$, dan meliputi 2 sekolah pendidikan usia dini (PAUD/TK), 2 sekolah dasar (SD/MI), 1 Sekolah menengah pertama ( SMP), dan 1 sekolah menengah kejurusan negeri (SMKN) sebagai sala satu sarana dan prasarana pendidikan, adapun sasaran utama pada kegiatan tersebut ialah:

1. Peserta didik SDN Barengkok 1.

2. Santriawan dan santriwati pengajian mushola Al - Istiqomah.

3. Peserta didik bimbingan belajar di RT 02 .

4. Santriawan dan santriwati taman pendidikan Al Quran mushola Al-Ibtida.

5. Masyarakat kampung Kandang Sapi.
6. Pendidik (guru) pendidikan anak usia dini kecamatan Leuwiliang.

Dari keenam khalayak sasaran di atas merupakan salah satu cikal bakal berlangsungnya kegiatan pembelajaran, dan diharapkan kegiatan pembelajaran tersebut dapat membawa hal yang baik serta uswatun hasanah untuk generasi selanjutnya, serta memberikan nilai-nilai pendidikan yang bermanfaat dan dapat diaplikasikan pada kegiatan sehari-hari bagi seluruh masyarakat.

\section{KESIMPULAN DAN IMPLIKASI}

\section{Kesimpulan}

Secara umum, belajar dapat diartikan sebagai proses perubahan perilaku, akibat interaksi individu dengan lingkungan. Dengan pengertian ini dapat dipahami bahwa perilaku itu mengandung pengertian yang luas. Hal ini mencakup pengetahuan, pemahaman, keterampilan, sikap dan sebagainya. Setiap perilaku ada yang Nampak dan ada pula yang tak nampak. Perilaku yang nampak disebut penampilan atau behavioral performance. Sedangkan yang tidak bisa diamati disebut kecenderungan perilaku atau behavioral tendency (Ali 2002).

Dan dikuatkan dengan persepsi bahwa pengetahuan, pemahaman, keterampilan, sikap, dan sebagian yang dimiliki seseorang tidak dapat diidentifikasi karena ini merupakan kecenderungan perilaku saja. Hal ini dapat diidentifikasi dari penampilan. Penampilan ini dapat berupa kemampuan menjelaskan, menyebutkan sesuatu atau melakukan sesuatu perbuatan. Jadi, kita dapat mengidentifikasi hasil belajar melalui penampilan

Tidak semua perubahan perilaku sebagaimana dideskripsikan di atas adalah hasil belajar. Ada diantaranya terjadi dengan sendirinya, karena proses perkembangan. Seperti halnya bayi dapat memegang sesuatu setelah mencapai usia tertentu. Keadaan ini bukan hasil belajar melainkan kematangan 
atau maturation. Ini merupakan faktor penting yang mempengaruhi hasil belajar.

Perubahan perilaku dalam proses belajar adalah akibat dari interaksi dengan lingkungan. Interaksi ini biasanya berlangsung secara disengaja. Sedikitnya ada tiga hal yang membuat seseorang melakukan proses belajar yaitu kesiapan/ readiness, motivasi dan tujuan yang ingin dicapai. Dengan demikian dapat dikesimpulkan bahwa belajar merupakan suatu proses dan aktivitas yang melibatkan seluruh indra yang mampu mengubah perilaku seseorang terhadap dirinya sendiri, orang lain dan lingkungannya.

Belajar juga merupakan suatu proses pengekplorasian terhadap suatu obyek yang dapat disintesis untuk menuju sempurna. Indikator adanya kegiatan belajar yaitu adanya perubahan tingkah laku, perubahan pola pikir, dan perubahan sikap, perubahan perilaku yang disebabkan oleh kegiatan belajar, pertama, perubahan perilaku secara subyektif, misalanya melamun. Bila kita melihat seseorang yang melamun, ia belum tentu diam, kemungkinan orang tersebut belajar, kedua, perilaku secara obyektif, misalnya melihat aktivitas dan sikap seseorang, misalnya membaca, latihan, dan perubahan pola pikiir dari sikap yang buruk ke sikap yang lebih baik. Kedua perubahan perilaku sebagai dampak orang tersebut belajar dipengaruhi unsur-unsur tertentu.

Unsur-unsur tersebut terdiri dari: pertama, motivasi, motivasi terdiri dari dua macam yaitu: motivasi intrinsik dan motivasi ekstrinsik. Motivasi intrinsik adalah dorongan dari dalam diri sendiri (kesadaran). Contoh, keinginan belajar yang berasal dari kesadaran diri sendiri. Motivasi ekstrinsik adalah dorongan yang berasal dari luar diri individu. Contoh, mengambil keputusan untuk belajar karena paksaan dari oarngtua. Motivasi ekstrinsik dapat berubah menjadi motivasi instrinsik karena ada faktor yang muncul dan berubah secara sungguh-sungguh sehingga dengan sendirinya kesadaran akan ada. Motivasi bersifat fluktuatif yaitu naik dan turun, kedua, adalah alat, misalnya, sarana (alat peraga, audiovisual, slide atau OHP), ketiga, bahan, GPPP, kurikulum dan silabus, dan kurikulum berkembang adanya tuntutan teknologi, keempat, situasi dan kelima, kondisi subyek seperti kesehatan, intelegensi.

Maka kami selaku mahasiswa Kuliah Kerja Nyata mengambil kesimpulan dari segala rangkaian kegiatan yang sudah terlaksana mulai dari kegiatan pembelajaran yang bersifat formal, nonformal, informal sampai dengan kegiatan sosialisasi, maka dapat diambil kesimpulan bahwa terciptanya pendidikan yang baik, maju dan berkualitas yaitu pendidikan yang dibantu serta didorong oleh masyarakat itu sendiri, dengan menanamkan kesadaran akan pentingnya pendidikan dimulai dari kalangan anak usia dini sampai kalangan orangtua, karena belajar merupakan kewajiban yang tak mengenal ruang dan waktu hanya kematianlah yang dapat memutuskannya, manusia yang memiliki ilmu dan berpendidikan ia akan hidup dimana saja karena ilmu yang telah diperoleh dari masa belajar akan menuntunnya kepada hal - hal yang baik di masa depan.

\section{Implikasi}

Melihat serta meninjau dalam kegiatan pembelajaran yang dilaksanakan oleh mahasiswa kuliah kerja nyata Universitas Djuanda Bogor di desa Barengkok, kampung kandang sapi telah berhasil mengayomi masyarakat untuk saling bahu membahu dalam meningkatkan mutu pendidikan di tempat tersebut, karena keberhasilan dan suksesnya pendidikan adalah tentang tanggung jawab bersama dalam memenuhi aspek-aspek pembelajaran dan pengajaran yang menjadi ujung tombak pendidikan. Untuk kedepannya kami bersama-sama mengharapkan pembelajaran seperti ini harus terus berjalan demi terciptanya mutu pendidikan di masyarakat, walau halnya kegiatan kuliah kerja nyata telah resmi ditutup. 


\section{UCAPAN TERIMA KASIH}

Kami sampaikan terima kasih kepada semua pihak yang telah berperan dan ikut serta dalam kegiatan pengabdian ini. Semoga Allah Swt meridhoinya, juga kami ucapkan terima kasih sebesar-besarnya kepada:

1. BAPPEDA, Selaku donator yang membantu kegiatan pengabdian dari awal sampai akhir;

2. Abdul Tawakal selaku Kepala Desa Barengkok yang memberikan kesempatan kepada kami untuk melaksanakan pengabdian masyarakat selama 39 hari.

\section{DAFTAR PUSTAKA}

Zamar A. 2016. Teori belajar \& pembelajaran (implementasi dalam bimbingan kelompok belajar di perguruan tinggi). Edisi Pertama. Media Akademi, Yogjakarta.
Sutarsyah C. 2016. Permasalahan di Indonesia. Edisi Pertama. Media Akademi, Yogjakarta.

DarmadHi. 2011. Metode penelitian pendidikan. Edisi Kedua. Alfabeta, Bandung.

Kemenag. 2003. Undang-undang Republik Indonesia Nomor 20 Tahun 2003 Tentang Sistem Pendidikan Nasional

Asrori M. 2015. Perkembangan peserta didik (pengembangan kompetensi pedagogis guru). Edisi Pertama. Yogjakarta.

Syahraini T. 2013. Membangun bangsa melalui pendidikan (gagasan pemikiran dalam mewujudkan pendidikan berkualitas untuk kemajuan bangsa Indonesia). Edisi Pertama. Graha Ilmu, Yogjakarta.

Tatang S. 2016. Supervisi pendidikan. Edisi Pertama. Pustaka Setia, Bandung.

Mulyana R. 2009. Optimalisasi Pemberdayaan Madrasah. Edisi Pertama. Aneka Ilmu, Semarang - Demak. 